\title{
Physical and Mechanical Properties of Asphalt Concrete Contain Reclaimed Asphalt Pavement from National Road in East Java Province Indonesia
}

\author{
Ari Widayanti' Ria Asih Aryani Soemitro, Januarti Jaya Ekaputri and Hitapriya Suprayitno
}

\begin{abstract}
Reclaimed Asphalt Pavement (RAP) is a paving stripping material with Cold Milling Machine. The RAP accumulation in East Java Province is estimated $50,000 \mathrm{~m}^{3}$ per-year. The RAP usage can decrease RAP accumulation, natural material, damage rate by mining or excavation. RAP mixture produced an optimum performances (workability, stability). RAP improved volumetric and mechanical properties of mixture. On the other hand, the usage of RAP increased the brittleness of pavement. It is necessary to support in microstructural aspect so the addition of RAP can produce better performance. The objective of this study is to obtain physical and mechanical properties of asphalt concrete contain RAP. Method used literature study. The result showed the physical properties of aggregate and asphalt RAP according the specification standard exception on gradation, penetration and ductility. The Asphalt Concrete with RAP include in specification standard, exception was in the range of $3.78-4.63 \%$, the optimum in VIM PRD. The asphalt content in RAP RAP of 20-30\%. RAP can be used as AC-WC, AC-BC, AC-Base. The strength of RAP depends on the source of RAP. The usage of RAP requires new or other material so it become the environment friendly material.
\end{abstract}

Index Terms - Reclaimed Asphalt Pavement, physical, mechanical, properties.

\section{INTRODUCTION}

T he roads are land transportation infrastructures that are highly crucial to support community activities, economic growth, regional development, and the distribution of goods and people. One section of the road which is formed from pavement structure will experience change with age service roads and traffic loads that take place. Such changes may include road damage which requires maintenance to improve the road service life. When reaching the End Surface Index, the pavement can be considered to bear no structural value again which need to overlay with new pavement. This condition will result in an increase the road elevation due to the repetitive coating process. Eventually, the pavement would need to be peeled, and its utilization needs to adapt to the field conditions. Reclaimed Asphalt Pavement

A. Widayanti is with the ${ }^{1}$ Department of Civil Engineering, Institut Teknologi Sepuluh Nopember, Surabaya, East Java, Indonesia (e-mail: ariwidayanti1973@gmail.com)

A.A. Soemitro is with the ${ }^{1}$ Department of Civil Engineering, Institut Teknologi Sepuluh Nopember, Surabaya, East Java, Indonesia

J.J. Ekaputri is with the ${ }^{1}$ Department of Civil Engineering, Institut Teknologi Sepuluh Nopember, Surabaya, East Java, Indonesia

H. Suprayitno is with the ${ }^{1}$ Department of Civil Engineering, Institut Teknologi Sepuluh Nopember, Surabaya, East Java, Indonesia.
(RAP) is a paving stripping material with Cold Milling Machine. The potential of RAP in East Java Province is estimated approximately 50,000 $\mathrm{m} 3$ per-year [1]. The usage of RAP material is still limited to the shoulder of road, patching of damaged of road, driveway in the houses and offices, parking areas.

The advantages of usage RAP consist of various aspects. It reduces the accumulation of RAP. The usage of RAP affects the cost efficiency, reduces the usage of natural resources and the damage by mining [1]. The usage of RAP enhances the environmental sustainability and capable of producing an optimum performance of mixtures [2]. The addition of RAP in mixture increases the stability [3] and the properties of mixture to better performance [4]. The usage of RAP in the asphalt concrete improves the volumetric, mechanical and performance properties of mixtures [5]. The addition of RAP produces better workability and higher stability [6]. RAP can influence the road's technical life and its resistance to deteriorate [7].

The disadvantages of usage of RAP consists of various aspects. The gradation of RAP doesn't include in Specification Standard $[8,9,10]$. The ductility of asphalt RAP doesn't meet in specification [9-14]. It is similar with the penetration [8-14]. The addition of RAP increases the brittle of asphalt concrete [3]. There was no consistency of change in addition to physical properties of mixtures in penetration, ductility and softening point [15].

The aims of this study were to obtain physical properties of RAP (aggregate and asphalt), chemical and mechanical properties of asphalt concrete contain of RAP from national road in East Java Province. The physical, chemical and mechanical properties were important to obtained information how bound the component material in pavement mixtures.

\section{LITERATURE REVIEW}

The Literature Review consists of Asphalt Concrete, Reclaimed Asphalt Pavement, RAP Process and Method, Physical Properties of RAP, Chemical and Mineralogy of RAP, Physical and Mineralogy of Asphalt Concrete.

\section{A. Asphalt Concrete}

Asphalt Concrete is a composite material that consists of mineral aggregate bound together with asphalt, laid in layers and compacted. It formed the structure that stable so that the vehicle can pass safely. It commonly used to roads, airports, parking area, driveways, and embankment dams. 


\section{B. Reclaimed Asphalt Pavement}

Reclaimed Asphalt Pavement (RAP) is a paving stripping material with Cold Milling Machine. The potential of RAP in East Java Province is estimated approximately $50,000 \mathrm{~m}^{3}$ per-year. The usage of RAP material is still limited to the shoulder of road, patching of damaged road, driveway in the houses and offices, parking areas.

\section{RAP Process and Method}

RAP is processed by extraction and recovery. Extraction process produces RAP aggregate and RAP asphalt. Recovery process is conducted to separate asphalt and forming material. RAP can be obtained from quarry by dredging with Cold Milling Machine or Full Depth Removal [16]. Based on the previous research, the gradation of Reclaimed Asphalt Pavement can be presented in Fig. 1.

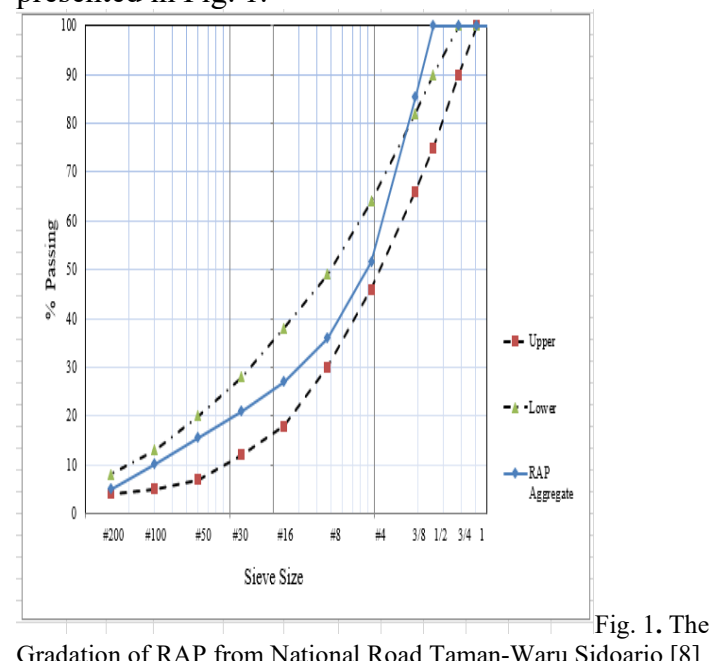

Gradation of RAP from National Road Taman-Waru Sidoarjo [8]

Fig 1 shows the gradation of RAP from national road Taman-Waru Sidoarjo was not according in specification standard of Bina Marga 2010 [8]. It was similar with other previous research [9-14]. The gradation of RAP showed that the gradation of RAP in number sieve passing of $3 / 8$ " and $1 / 2$ " exceeded from the specification standard.

\section{Physical Properties of RAP}

Physical properties of RAP can be obtained by testing of RAP aggregate and RAP asphalt. Aggregate/rock is defined as materials that consist of solid minerals, in the form of large-sized mass or in the form of fragments. In asphalt mixtures, aggregate contributes $90-95 \%$ to the weight of mixtures, thus, the properties of aggregate are one of the mixture's performance. Aggregates are usually classified by size as coarse aggregates, fine aggregates or mineral fillers. Aggregates are generally required to be hard, tough, strong, durable, properly graded; to consist of cubical particle with low porosity; and to have clean, rough, hydrophobic surfaces. The suitability of aggregates is determined by evaluating the following material characteristic as size and gradation, cleanliness material, toughness/hardness, durability/soundness, surface texture, particle shape, absorption and affinity for asphalt [17].
The sizes of the aggregate in an asphalt mixture are distributed from large too small. The larger the maximum size of aggregate used, the more variations in size in the mixture. Gradation is the distribution of grain size variation. Aggregate grading affects a number of cavities in the mix and determined the workability and stability of the mixture. Aggregate gradation is divided into uniform gradation, gradation and gradation gap meetings. Cleanliness is the aggregate limit the type and amount of unwanted materials (such as plants, soft particles, mud etc.) are in or attached to the aggregate. Aggregates gross will give bad influence on pavement performance, such as reduced bonding between the asphalt and aggregates due to the excessive clay content in the aggregate.

All aggregates used must be capable of withstanding degradation and disintegration during process of production and operation in the field. Degradation is the destruction of aggregates as a result of the force applied at the time of accumulation, compaction and traffic load. Meanwhile, disintegration is influenced by chemical weathering such as humidity and temperature differences. Particle shape can affect the workability mixture over the pavement, in compaction namely in terms of the energy required for compressing the mixture and the strength of the pavement structure during the life of technique. Aggregates are angular shaped cubes and aggregates that have more than one field broken the bond between aggregate will produce the best.

In addition to providing skid resistant properties on the pavement surface, the surface texture of aggregates (both macrostructure and microstructure) is also another factor that determines the strength, ease of workability and durability of the asphalt mixture. The surface coarse aggregate which will provide power to the asphalt mixture for an aggregate surface roughness can withstand the aggregate of shift or displacement. The aggregate's surface roughness will also provide a strong frictional resistance on vehicle's wheels that will improve vehicles' safety from slipping.

The porosity determines the amount of liquid that can be absorbed by the aggregate. If the aggregate has very high absorption power, it will continue to absorb aggregate asphalt both during and after the process of mixing the aggregate with bitumen in the asphalt mixing unit. This will cause the asphalt on the aggregate's surface that is beneficial to bind the aggregate particles to become smaller so that it will produce thin layers of asphalt. The affinity of the asphalt aggregates is the aggregates tendency to accept, absorb and hold the layer of asphalt.

The physical properties of asphalt crucially affect in design, producing and performance of asphalt mixtures. Physical testing of asphalt cements can be categorized as Consistency Test (absolute viscosity at $140^{\circ} \mathrm{F}$, kinematic viscosity at $275^{\circ} \mathrm{F}$, penetration, softening point, ductility), Durability Tests (Thin Film Oven Test, Rolling Thin Film Oven Test), Purity Test, Safety Test, Other Test (Specific Gravity, Spot Test) [17].

Properties of asphalt change significantly due to oxidation and feeling occurring at the time of mixing, transporting and spreading in the field. Asphalt's ability to inhibit the rate of aging is called Asphalt Durability. Asphalt durability testing aims to find out how well 
asphalt to retain its initial properties due to the aging process. Quantitative tests conducted to determine the durability of asphalt are penetration, softening point, weight loss and ductility. This test is performed on specimens that have undergone Thin Film Oven Test (TFOT) and Rolling Thin Film Oven Test (RTFOT).

Ductility test is a quantitative test that indirectly can be used to know the ability of asphalt particles to attach to each other. Hard asphalt with low ductility is asphalt that has poor cohesion compared with asphalt with high ductility. Asphalt seal testing of rocks is another qualitative test. It is used to identify asphalt adhesion to rocks.

Asphalt is thermoplastic material that becomes harder when the temperature decreases and softer when the temperature increases. The sensitivity of asphalt to change properties due to temperature changes is known as the asphalt sensitivity to temperature. Penetration and viscosity are the sensitive asphalt properties of temperature. Knowledge of asphalt sensitivity to temperature is useful to know asphalt temperature and aggregate temperature can be mixed and compared.

The aging process due to short-term and long-term oxidation causes hardening of asphalt. It increases the rigidity of asphalt mixtures thereby affecting mixed performance. The increasing of stiffness can increase the resistance of mixture to permanent deformation and the ability to spread the loading received. On the other hand, it causes the mixture to become more brittle resulting in rapid cracking and lower resistance to repetitive loading.

E. Chemical and Mineralogy Properties of RAP

Chemical and mineralogy of RAP can be obtained from XRF, XRD, SEM and FTIR tests. The largest composition of RAP material is kaolin. The major compositions of RAP consist of Kaolin, Lithium, Tetraborate and Dextrin. It indicates the presence of rock elements because RAP consist of asphalt and aggregate components that have become a unity. SEM graphic present morphology and surface texture of RAP. The majority of RAP material consists of sub angular and angular, very rough surface texture. It will be good to make pavement structure because it can improve interlocking aggregate in road pavement. RAP band molecule at peak shows $\mathrm{O}-\mathrm{H}$ (alcohol) and C-H (carbon). The major compound of RAP by XRD test shows Calcium, Sodium, Aluminium and Silica [18].

\section{F. Physical and Mechanical Properties of Asphalt Concrete}

Current test of asphalt concrete consists of physical properties and mechanical properties. Physical properties consist of air voids, voids filled with asphalt/bitumen, voids in mineral aggregate, aging. Mechanical test can be conducted by Marshall Stability, Hveem Stabilometer, Cohesiometer, Modulus of Elasticity, Resilient Modulus (Repeated Load Indirect Tensile), Stiffness Modulus by Indirect Means, Dynamic Complex Modulus, Flexural Test, Indirect Tension, Creep and Permanent Deformation, Gyratory Testing Machine (GTM), Laboratory Wheel Tracking Tests, Moisture Susceptibility Tests [17].
The purpose of designing of mixture is to determine the proportion of material to achieve the desired end-mix proportion [17], among others:

1. Stability is the ability of asphalt mixture to receive traffic loads without permanent deformation such as waves, grooves and so on.

2. Fatigue Resistance is the resilience of asphalt mixture to receive repetitive loading without the occurrence of fatigue in the form of grooves and cracks.

3. Durability is the ability of asphalt mixture to maintain its quality against damage road due to weather, water and traffic load.

4. Water Resistance is a mixture resistance from water that can cause the loss of adhesion between the aggregate and asphalt in the surface layer.

5. Skid Resistance is a mixture aggregation as a surface layer so the traffic can pass without slip during rain or wet condition.

Workability is the ease of the mixture to be overlaid and compacted so as to obtain the desired degree of density.

\section{RESUlTS AND DisCUSSION}

Based on the previous research, the properties of RAP aggregate, RAP asphalt and asphalt concrete can be presented in Table I, Table II and Table III. Table I shows that aggregate weathering over the lifetime has little effect on the physical properties of RAP aggregate. It can be presented from the eternity of aggregate shape after being immersed in a solution of magnesium sulphate and abrasion. Both values show resistance aggregate from degradation and disintegration during production and operation. This is due to the asphalt layer that has enveloped the RAP aggregate. However, the affinity of RAP aggregate to asphalt still meets the requirements of the specification. It is expected to still accept, absorb and retain the asphalt thickness of the film in accordance with the technical specifications. The flattered and elongated particle of RAP aggregate is below the maximum limit of specifications. It shows RAP aggregate has a rough surface and cubical shape. With the fulfilment of this characteristic, it is hoped that the mixtures of pavement with RAP resulted in high stability due to better interaggregate interlocking.

Table II shows that the physical properties of RAP asphalt increase as compared to specification. However, the penetration of RAP asphalt is below the specification standard for the type of asphalt used. The viscosity of RAP asphalt is for above the minimum standard of specification. The penetration and viscosity are characteristic of the asphalt which shows the level of hardness/stiffness of the asphalt at a certain temperature. The low penetration and high viscosity of the RAP asphalt showed that RAP asphalt had high hardness and stiffness. The increasing of hardness and stiffness asphalt can increase stability of mixtures. On the other hand, it causes the mixture to become more brittle.

Ductility test was conducted to determine the cohesion properties of RAP asphalt. Cohesion is the asphalt's ability to keep the aggregate firmly in place after binding. The high ductility of RAP asphalt indicates the high cohesion/ability of hard asphalt particles to adhere to one 
another so as to bind the aggregate grains well. While the low ductility of RAP asphalt indicates low cohesion/ability of hard asphalt particles to adhere to one another so as to bind the aggregate grains well. The test results of softening point of RAP asphalt ranges from 55$65.5^{\circ} \mathrm{C}$. This value is above the minimum standard of the Pen $60 / 70$ asphalt specification ranging from $40^{\circ} \mathrm{C}$. It indicates that pavement with asphalt RAP are more resistant to form changes due to high temperatures in the field, as the RAP asphalt begins to soften at higher temperatures. The affinity of asphalt is influenced by the mechanical and chemical properties of aggregate. Mechanical properties include pores and absorption, surface shape, texture and grain size. Porous aggregates are good for causing strong bonds between aggregates and asphalt. But if too many pores will cause too much asphalt is absorbed so that the asphalt layer becomes thin. Cube shaped and rough aggregates prefer to bind asphalt rather than round shape and smooth aggregates. Rough aggregates surfaces provide better bonds with bitumen than aggregates with smooth surfaces.

The adhesion to the asphalt is influenced by the aggregate properties of water. Granite and rocks containing silica are hydrophilic aggregates that are easily aggregate to water. This type of aggregate is not well used as a mixture material with asphalt because it will easily occur stripping that is removal of the asphalt layer from aggregate because of the influence of water. The opposite condition, aggregates such as diorite andesite called hydrophobic aggregates. Hydrophobic aggregates are not readily bonded with water so the bonds between aggregates and asphalt are good enough, and the stripping is very small. Aggregates grain size is associated with gradation curve for RAP aggregate.

By comparing the physical properties of RAP to the specification, it is obtained that RAP aggregate characteristic meet the requirements of the specification in all test parameters, so that it can be used as a pavement material. Characteristic of RAP asphalt meet the requirements of the specifications on viscosity and softening point. Parameter penetration and ductility do not meet the requirement on specification. It is necessary to add RAP with new asphalt or other material to improve the physical properties of pavement mixtures.

Based on Table III, the volumetric characteristics (VIM, VMA, VFB) showed results in the VIM specification of $4-4.825 \%$, VMA of $14.941-15.867 \%$, VFB of $65-87 \%$. The volumetric characteristic factors affect the durability of pavement (NAPA, 1996). VMA should provide enough space for VIM and VFB. VIM must be within the specified range so as not to be too large to cause asphalt oxidation, or too small so that there is insufficient space for asphalt drainage due to traffic loading.

VFB and gradation determine the asphalt thickness of the film that affects the speed of oxidation asphalt and water absorption. VIM and VMA are inversely proportional to the density achieved by the mixture. The higher of the mixture density means the larger the cavity filled by the bitumen or filler thus minimizing the VIM and VMA. The increasing of density (up to a certain asphalt content) are caused by an increase in mixed asphalt content to lubricate particles in the mixture so that compaction efforts take place better.

The VIM in PRD meets the requirements except in research $[8,10]$ with a low value that is below 1 . This is likely due to an overcrowding value. The Bina Marga Specification 2010 Revision 3 [19] requires a minimum $2 \%$ VIM PRD. It is intended to maintain the durability of the mixture in good condition, due to the compaction by heavy traffic with high temperatures in the field. The low VIM causes the asphalt layer to melt out called bleeding, if there is a traffic load that adds layer compaction.

Stability is the maximum load that can be achieved by the mixture expressed in load unit. It is an indicator of pavement strength to carry the traffic load. The Marshall Stability for all mixtures can be achieved and meet the standard specification ranging from $830.482-2,655.22 \mathrm{~kg}$. This value depends on the planned pavement layer i.e. AC-Wearing Coarse, AC-Binder Coarse or AC-Base.

The flow shows of $3.26-5.74 \mathrm{~mm}$. The high flow indicates the plastic mixtures. Factors that caused plastic mixtures are thought to be due to high viscosity and low penetration. The larger viscosity of RAP asphalt and smaller RAP penetration than the viscosity and asphalt penetration cause the RAP percentage to be higher. It can increase the flow values. 
TABLE I

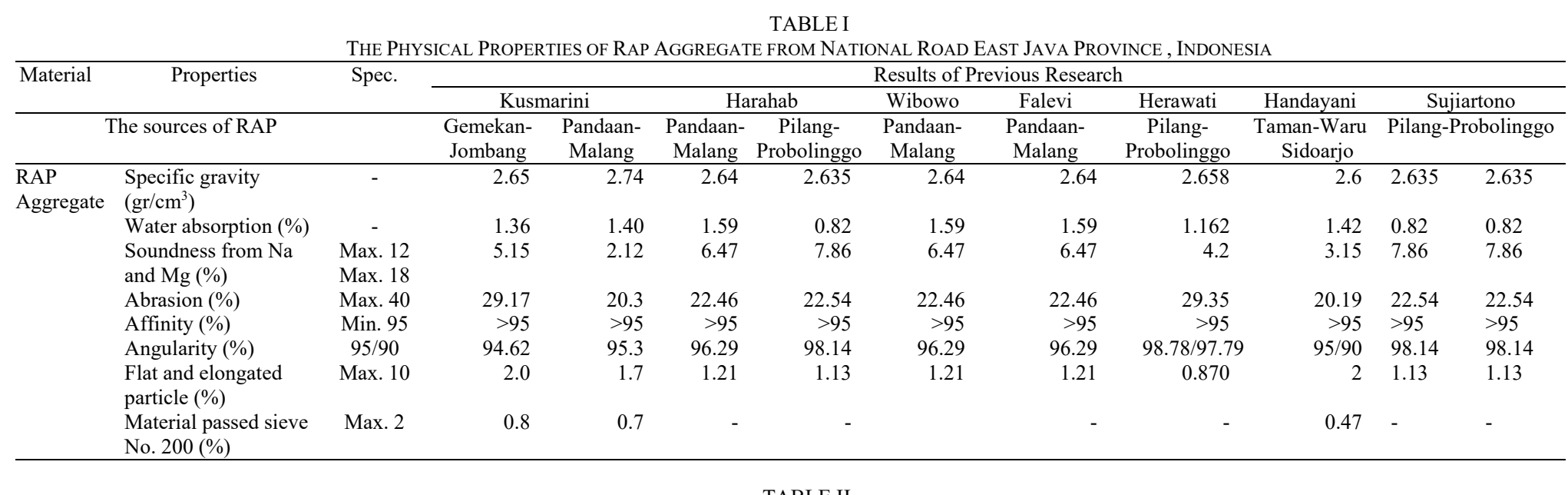

TABLE II.

\begin{tabular}{|c|c|c|c|c|c|c|c|c|c|c|c|c|}
\hline \multirow[t]{3}{*}{$\begin{array}{l}\text { Material } \\
\end{array}$} & Properties & \multirow[t]{3}{*}{ Spec. } & \multicolumn{10}{|c|}{ Results of Previous Research } \\
\hline & \multirow{2}{*}{ The sources of RAP } & & \multicolumn{2}{|c|}{ Kusmarini } & \multicolumn{2}{|c|}{$\begin{array}{l}\text { Harahab } \\
\text { Dil }\end{array}$} & \multirow{2}{*}{$\begin{array}{c}\text { Wibowo } \\
\text { Pandaan- } \\
\text { Malang } \\
\end{array}$} & \multirow{2}{*}{$\begin{array}{c}\text { Falev1 } \\
\text { Pandaan- } \\
\text { Malang } \\
\end{array}$} & \multirow{2}{*}{$\begin{array}{c}\text { Herawatit } \\
\text { Pilang- } \\
\text { Probolinggo }\end{array}$} & \multirow{2}{*}{$\begin{array}{c}\text { Handayanan } \\
\text { Taman-Waru } \\
\text { Sidoarjo }\end{array}$} & \multirow{2}{*}{\multicolumn{2}{|c|}{$\begin{array}{l}\text { Sujiartono } \\
\text { Pilang-Probolinggo }\end{array}$}} \\
\hline & & & $\begin{array}{l}\text { Gemetan- } \\
\text { Jombang }\end{array}$ & $\begin{array}{l}\text { Pandaan } \\
\text { Malang }\end{array}$ & $\begin{array}{l}\text { Pandaan- } \\
\text { Malang }\end{array}$ & $\begin{array}{l}\text { Pilang- } \\
\text { Probolinggog }\end{array}$ & & & & & & \\
\hline \multirow{4}{*}{$\begin{array}{l}\text { RAP } \\
\text { Asphalt }\end{array}$} & Bitumen content in & - & 4.6 & 3.78 & 4.63 & 4.15 & & & & & 4.18 & 4.18 \\
\hline & Penetration in $25^{\circ} \mathrm{C}$ & $60-70$ & 21 & 22 & 21 & 19 & 21 & 21 & 19 & 49 & 19 & 19 \\
\hline & Viscosity $135^{\circ} \mathrm{C}(\mathrm{cSt} t)$ & $\geq 300$ & 1.440 & $1.62-3$ & 50 & 2.300 & 1.950 & 1.950 & 50 & 2.300 & 2.300 & 2.300 \\
\hline & 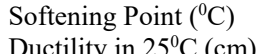 & $\begin{array}{l}\geq 48 \\
>100\end{array}$ & $\begin{array}{c}62.4 \\
19\end{array}$ & $\begin{array}{l}62.0 \\
2.3\end{array}$ & 57.5 & $\begin{array}{c}65.5 \\
19\end{array}$ & $\begin{array}{l}57.5 \\
24\end{array}$ & $\begin{array}{l}57.5 \\
24\end{array}$ & $\begin{array}{l}64.8 \\
11.5\end{array}$ & $\begin{array}{c}55 \\
>120\end{array}$ & $\begin{array}{c}65.5 \\
19\end{array}$ & 65.5 \\
\hline
\end{tabular}




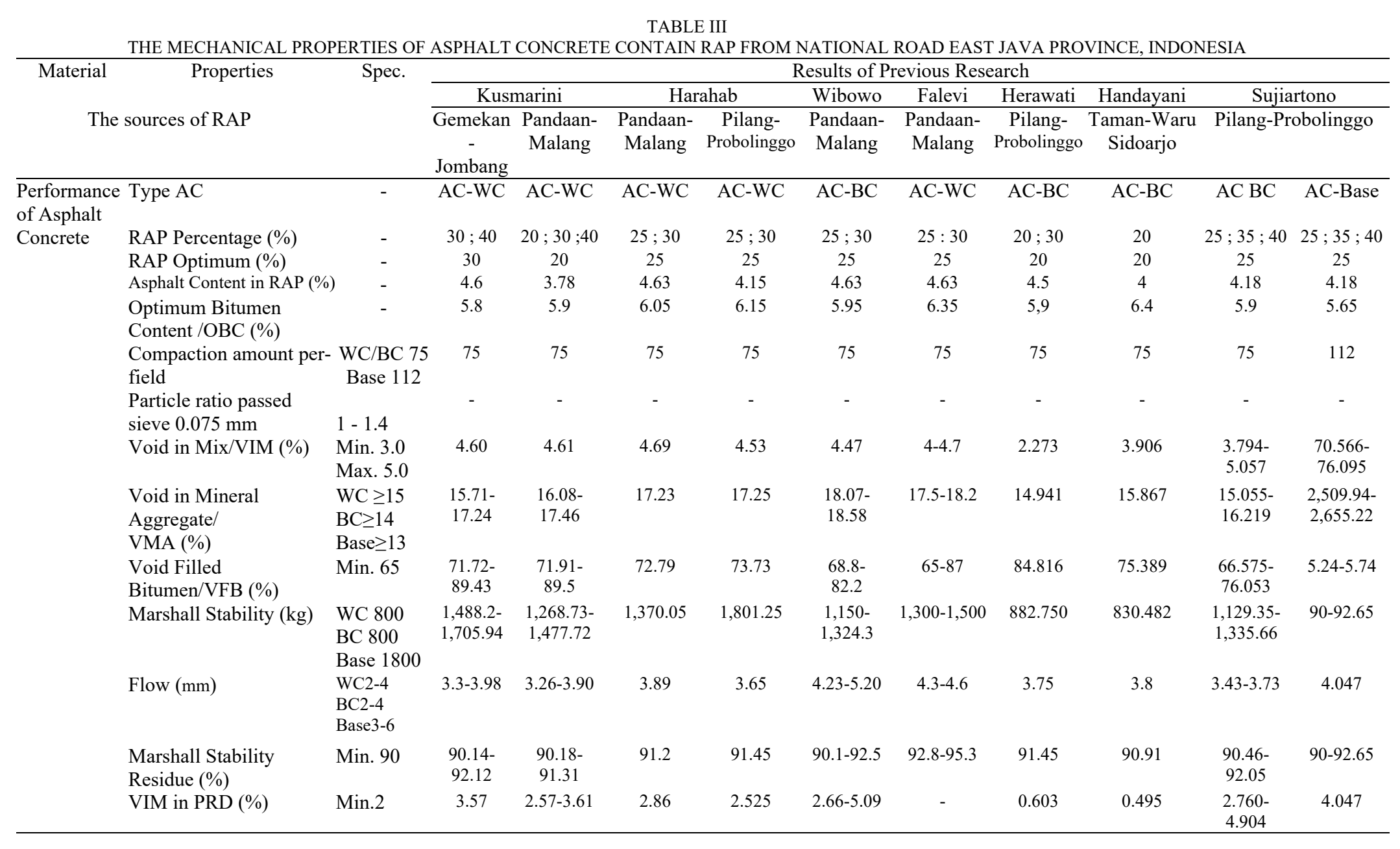




\section{CONCLUSION AND RECOMMENDATION}

Based on the result and discussion, the RAP development in Indonesia and other countries can produce conclusions as follow:

1. Physical properties of RAP aggregate show the result meet the specification except on the aggregate grading curve. Physical properties of asphalt RAP meet requirement in specification except on penetration and ductility values.

2. Chemical properties of RAP show that the compositions of $\mathrm{RAP}$ consist of $\mathrm{Si}, \mathrm{Al}$ and $\mathrm{Ca}$. It indicates that RAP contains rocks resulting in a hard and stable material.

3. RAP can be used in AC-WC, AC-BC, AC -Base layer. RAP usage percentages of $20-40 \%$, optimum RAP of 20 $30 \%$, asphalt content in RAP of 3.78-4.63\%, VIM of 4$4.825 \%$, VMA of $14.941-15.867 \%$, VFB of $65-87 \%$, Marshall Stability of 830.482-2655.22 kg, flow of 3.26$5.74 \mathrm{~mm}$, Residue Marshall Stability of 90.1-92.65 kg, VIM in PRD of $2.525-5.09 \%$. Mechanical properties of asphalt concrete contain RAP produce the technical performance mixtures with RAP meet the requirements of the Revised 3 of Bina Marga Specification 2010 except in VIM PRD.

The recommendation can be obtained from this research as follow:

1. To the relevant institution is the strength of the RAP highly depended on the source of the RAP.

2. RAP usage strategy as road pavement material needs to be added with new material or other material so that it can became environment friendly material.

\section{ACKNOWLEDGEMENT}

The research in degree scholarship is provided by Ministry of Technology Research and Higher Education, Ministry of Finance by LPDP/Fund Managers.

\section{REFERENCES}

[1] H. Budianto, "Menuju Jalan yang Andal," Surabaya, 2009.

[2] A. Widger, F. Skilnick, and E. Zabolotnii. "Engineer-In-Training Clifton Associated Ltd. Communities of Tomorrow, Leveraged Municipal Innovation Fund," 2012.

[3] Parveez, Prateek, Srikanta, Yathiraj, Konnur, and Dinesh, "Study on the Effect of Reclaimed Asphalt Pavement (RAP) on the Mechanical Behaviour of Hot Mix Asphalt," India, 2013.

[4] Pradyumna, T. Anil. Mittal, Abhishek, and P.K Jain, "Characterization of reclaimed asphalt pavement (RAP) for use in bituminous road construction," Procedia-Social and Behavioral Sciences. 104, 11491157, 2013.

[5] J. Shen, S. Amirkhanian, and J.M.Aune, "Effects of rejuvenating agents on superpave mixtures containing reclaimed asphalt pavement," Journal of Materials in Civil Engineering, 19.5: 376-384, 2007.

[6] F. Xiao, S.N. Amirkhanian, J. Shen, and B. Putman, "Influences of crumb rubber size and type on reclaimed asphalt pavement (RAP) mixtures," Constr. Build. Mater. 23, 1028-1034. 2009.

[7] F. Xiao, S.N Amirkhanian and J. Shen, C., "Rutting resistance of rubberized asphalt concrete pavements containing reclaimed asphalt pavement mixtures," Journal of Materials in Civil Engineering, 19.6, 475-483, 2007.
[8] R. Handayani, R.A.A Soemitro, H. Budianto, and J.J Ekaputri, International Seminar on Science and Technology, ITS, 2016.

[9] E.P. Kusmarini, R.A.A Soemitro, and H. Budianto, "Analisis Penggunaan Reclaimed Asphalt Pavement (RAP) dan Aspal Pen 60-70 sebagai Bahan Campuran Beraspal Panas (Asphaltic Concrete)(Studi Kasus Ruas Jalan Gemekan-Jombang dan Pandaan-Malang)," Prosiding Seminar Nasional Aplikasi Teknologi Prasarana Wilayah (ATPW) Surabaya. Vol. 11, 2012.

[10] N. Herawati, R.A.A Soemitro, and H. Budianto, "Analisis Penentuan Komposisi Optimal Penggunaan Reclaimed Asphalt Pavement (RAP) sebagai Bahan Campuran Beraspal Panas (Asphaltic Concrete) Menggunakan Aspal Modifikasi (Studi Kasus Jalan PilangProbolinggo)," Prosiding Seminar Nasional Aplikasi Teknologi Prasarana Wilayah (ATPW) Surabaya, Vol. 11, 2012.

[11] S. Harahab, R.A.A Soemitro and H. Budianto, "Optimalisasi Penggunaan Reclaimed Asphalt Pavement (RAP) sebagai Bahan Campuran Beraspal Panas (Asphaltic Concrete) Tipe AC-Wearing Course (ACWC) Gradasi Kasar dengan Aspal Pen 60-70 dan Aspal Modifikasi Jenis TRS 55 (Studi Kasus Jalan Nasional Pandaan-Malang dan Jalan Nasional Pilang-Probolinggo)," Prosiding Seminar Nasional Pascasarjana XIII - ITS, Surabaya 15 Agustus 2013, ISBN No. 978979-96700-6. Vol. 9, 2013.

[12] H. W. Wibowo, Tesis Pasca Sarjana. ITS Surabaya, 2012.

[13] R. Falevi, Tesis Pasca Sarjana. ITS, 2012.

[14] A. Sujiartono, Tesis Pasca Sarjana. ITS Surabaya, 2014.

[15] S. Sunil, Mallesh, and K.M., Chandrasekaraiah, "Experimental investigations on the performance of bituminous mixes with reclaimed asphalt pavement (RAP) materials (case study Tumkur to ChitradurgaNH4)," IJRET International Journal of Research in Engineering Technology, 3.6: 297-303, 2014.

[16] TRB. "A Manual for Design of Hot Mix Asphalt with Commentary". National Cooperative Highway Research Program (NCHRP). Report 673. Washington DC, USA 2011.

[17] F.L. Roberts, P.S. Kandhal, E.R. Brown, D.Y. Lee and T.W. Kennedy. "Hot Mix Asphalt Materials, Mixture Design and Construction," Second Edition, NAPA Research and Education Foundation. Lanham Maryland, 1996.

[18] A. Widayanti, R.A.A Soemitro, J.J. Ekaputri, H. Suprayitno, Proceeding ISTSDC 1. Universitas Hasanudin. Makasar-Indonesia, 2017.

[19] Spesifikasi Bina Marga Tahun 2010 Revisi 3, 2010. 